\title{
Acquired Tolerance in Apricot Plants that Stably Recovered from European Stone Fruit Yellows
}

R. Osler, S. Borselli, P. Ermacora, A. Loschi, M. Martini, R. Musetti, and N. Loi, Department of Agricultural and Environmental Sciences, University of Udine, via delle Scienze, 206, I-33100 Udine, Italy

\begin{abstract}
Osler, R., Borselli, S., Ermacora, P., Loschi, A., Martini, M., Musetti, R., and Loi, N. 2014. Acquired tolerance in apricot plants that stably recovered from European stone fruit yellows. Plant Dis. 98:492-496.

European stone fruit yellows (ESFY) is one of the most destructive phytoplasma diseases of plum, apricot, and peach in Europe. Conventional preventive defense strategies have been ineffective. Because apricot cultivars with innate-constitutive resistance against ESFY are not available, the aim of this more than 20-year-long study was to seek acquired resistance or tolerance. In the first experiment, we surveyed an orchard with seven apricot cultivars for 12 years in an area of northern Italy with a high rate of natural occurrence of ESFY. Of the diseased plants, a few $(8.7 \%)$ became completely symptomless but retained the phytoplasma, as confirmed by polymerase chain reaction (PCR). In the second experiment, we grafted buds from two stably recovered plants and from two nonrecovered plants onto 'Rubira'

peach. Over the next 9 years in an orchard with a high rate of natural infection, $93.0 \%$ of the "nonrecovered clones" became diseased but only $1.5 \%$ of the plants grafted with the two "recovered clones" developed ESFY symptoms. According to PCR analyses, all of the exposed test plants were ESFY-infected, whether they were derived from recovered or nonrecovered mothers. This could indicate that epigenetic changes occurred in recovered plants due to a graft-transmissible memory. Based on the results attained from the two described experiments, we propose that an acquired tolerance that occurred in stably recovered apricot trees was graft transmitted from two tolerant apricot clones. In contrast, we did not demonstrate a cross-protection process based on protectant avirulent phytoplasma strains that suppress severe strains.
\end{abstract}

Phytoplasmas (22) are wall-less bacteria that reside and duplicate exclusively inside phloem sieve elements of host plants and within insect vectors (46). Phytoplasmas are transmitted in nature by phloem-sap-feeding insects in a persistent and circulative manner (50). They can also be transmitted by vegetative propagation of plants; in particular, by grafting. Mainly depending on the cultivar, the rootstock, and the phytoplasma itself, the yield in diseased plants generally ranges from poor to nil, and the plants gradually decline and can die prematurely. Strain variants of a single phytoplasma species appear to be common $(17,21,28,47)$.

Apple proliferation (AP), pear decline (PD), European stone fruit yellows (ESFY), flavescence dorée (FD), and bois noir (BN) represent important examples of phytoplasma diseases that can devastate commercial fruit and grape production. These diseases share a high potential for rapid, persistent, and recurrent epidemics but also have the capacity for some diseased plants to recover.

Recovery is an induced or natural phenomenon reported for plants infected with different pathogens, including bacteria $(16,43)$ and phytoplasmas. Concerning phytoplasmas, recovery was first described in France in grapevines infected by FD phytoplasma (10), then in AP-infected apple (20), in apricot infected by ESFY (32), and in grapevines infected with BN $(26,41)$. Recovery was defined as the spontaneous remission of the symptoms but it may also involve the disappearance of the pathogen from the infected host (31). Remission of symptoms can be permanent (stable recovery) or temporary (43). Different primary causes of recovery have been advanced, such as the intervention of fungal and bacterial endophytes $(7,30,36)$ or abiotic stress $(19,41)$. Abiotic and biotic agents already known to induce systemic acquired resistance have been also hypothesized to be involved in recovery $(1,13,44)$. Recent results obtained by investigating the physiological and genetic

Corresponding author: R. Musetti, E-mail: rita.musetti@uniud.it

Accepted for publication 8 October 2013.

http://dx.doi.org/10.1094/PDIS-03-13-0342-RE

(c) 2014 The American Phytopathological Society bases of recovery (37-40) supported a strict correlation between recovery and a type of acquired or induced resistance in the host plant. Very recently, it has been shown that AP induced an increase in salicylate in apple plants, followed by a decline accompanied by a subsequent increase of jasmonic acid (JA) during recovery (42). This result has been confirmed by showing an overexpression of three genes encoding for key enzymes of the JA pathway (35). All of these features are also widely reported for acquired or induced resistance phenomena $(1,13,49)$.

As reported above, ESFY is one of the most destructive diseases of plum, peach, and apricot in many European countries $(12,27)$. Starting from the third to the fifth year after planting, infected orchards are no longer economically sustainable because of the high percentage of dead or severely declining plants. Conventional preventive defense strategies consisting of vector control and rogueing (followed by replacement using certified but susceptible plants) have been ineffective in the past. This suggests that the availability of plants showing some kind of resistance or tolerance to ESFY is essential for continuing the cultivation of apricot in infected areas. The lack of commercial apricot cultivars resistant to ESFY stimulated our efforts to search for acquired or induced resistance or tolerance. It was already known that diseased apricot plants can spontaneously and stably recover from ESFY when grown in highly infected areas $(8,34)$. In our work, we searched for apricot with acquired or induced resistance or tolerance by looking for apricot trees that had spontaneously recovered from ESFY. The status of "stable recovery" was used in this context as a signal of acquired or induced resistance or tolerance in individual plants.

In particular, specific aims of this work were to (i) search for spontaneously and stably ESFY-recovered apricot trees having characteristics of acquired or induced resistance or tolerance and (ii) verify whether the "progeny" of the stably recovered plants continued to show tolerance to ESFY that could enable them to serve as mother plants to propagate tolerant clones.

\section{Materials and Methods}

The research basically consisted of two consecutive experiments. 
Experiment 1: the search for spontaneously and stably ESFY-recovered apricot plants. In 1989, an orchard was established at Spessa (Udine province, Friuli Venezia Giulia, northeast Italy) that is known for its constant high natural pressure of ESFY infections. The orchard consisted of 170 apricot trees of seven old cultivars (extensively cultivated at that time in Italy) grafted on Myrobalan 29 B (Table 1) and grown according to organic agriculture methods. In particular, no insecticide treatments were applied.

Starting in 1989, the reaction of the apricot test plants exposed to the natural ESFY infections was followed by visual inspections (four visits/year) for 12 years (1989 to 2000). Particular attention was focused on previously symptomatic trees that had become spontaneously and stably nonsymptomatic (recovered plants).

After 1998, apricot plants were also tested by nested polymerase chain reaction (PCR) to confirm the presence or absence of phytoplasmas. DNA was extracted from $1.0 \mathrm{~g}$ of midveins using a phytoplasma enrichment procedure (2) or a cetyltrimethylammonium bromide extraction method (30). The presence of ESFY phytoplasma was assessed by nested-PCR using about $20 \mathrm{ng}$ of total genomic DNA. The first PCR run was performed with universal primers $\mathrm{P} 1 / \mathrm{P} 7$ or P1/16S-SR $(11,23,45)$, followed by a second run with group-specific primers fO1/rO1 (25) after a 1:30 dilution.

The PCR conditions were the following: initial denaturation at $94^{\circ} \mathrm{C}$ for $2 \mathrm{~min}$; 35 cycles consisting of denaturation at $94^{\circ} \mathrm{C}$ for 1 min, annealing at $55^{\circ} \mathrm{C}$ (or $50^{\circ} \mathrm{C}$ in the second run) for $1 \mathrm{~min}$, and extension at $72^{\circ} \mathrm{C}$ for $2 \mathrm{~min}$; and final extension at $72^{\circ} \mathrm{C}$ for $8 \mathrm{~min}$. Amplification products were analyzed by $1 \%$ agarose gel electrophoresis.

Restriction fragment length polymorphism (RFLP) analyses with $R s a \mathrm{I}$ and $S s p \mathrm{I}$ restriction enzymes were performed on fO1/rO1 PCR products in order to confirm the presence of ESFY phytoplasma. Restriction profiles were compared with those of phytoplasma reference strains AP15 (AP phytoplasma, 16SrX-A), PD1 (PD phytoplasma, 16SrX-C), and LNp or LNS2 (ESFY phytoplasma, 16SrX-B) maintained in periwinkle, used in nestedPCR as positive controls.

Negative controls, i.e., healthy apricot plants and PCR mixture without DNA template, were opportunely used in DNA extraction and nested-PCR procedures, respectively.

Experiment 2: maintenance of the tolerance in the "progeny" of the apricot plants that stably recovered. In 2000, two stably recovered (R1 and R2) and two nonrecovered symptomatic plants (NR1 and NR2) of the heirloom 'Bulida' obtained from experiment 1 were selected. These four mother plants were successively cloned by grafting on 'Rubira' peach, a rootstock that confers ESFY susceptibility to the scion $(12,19)$, to obtain a total of 139 plants: $32 \mathrm{R} 1,36 \mathrm{R} 2,50 \mathrm{NR} 1$, and $21 \mathrm{NR} 2$ plants. In spring 2003, the newly obtained plant populations R1, R2, NR1, and NR2 were distributed in an area of Friuli Venezia Giulia characterized by highly endemic ESFY pressure (15). From 2003 to 2011, plants were surveyed every year as previously described and assayed with PCR. For each of the different field trials, the following were calculated: the annual rate of newly ESFY-symptomatic trees in the orchard (disease incidence), the cumulative proportion of plants that became diseased during 9 years (disease prevalence), the proportion of plants that were positive to PCR tests (plant infectivity rate), and the rate of tree death (plant mortality) (Tables 2 and 3). In particular, the mean natural risk of plants exposed for 9 years becoming diseased or symptomatic, solely infected (nonsymptomatic), or dying was calculated and compared between the plant populations R1 + R2 and NR1 + NR2 (Table 4). Fruit production and growth of plants in the different trials were also investigated. Plant growth was evaluated by measuring the mean circumference of the trunk in 2011.

Statistical analyses were performed using GraphPad InStat version 3.10, 32 bit for Windows (GraphPad Software; www.graph pad.com). The statistical significance of the experiments was evaluated performing Mann-Whitney (one-tailed, not paired) nonparametric test.

\section{Results}

Experiment 1: the search for spontaneously and stably recovered ESFY apricot plants. During the 12 years (1989 to 2000) of natural spread of ESFY at Spessa, 115 of 170 plants $(67.6 \%)$ became symptomatic, $22(12.9 \%)$ died, and $33(19.4 \%)$ never exhibited visible symptoms of the disease. Of the 115 symptomatic plants, $10(8.7 \%)$ completely and stably recovered from the disease (Table 1). Among the seven cultivars considered in this experiment, Bulida, 'Cafona', and 'Reale d'Imola' were the most interesting ones, showing a comparable average of stable recovery $(8.3,8.3$ and $9.1 \%$, respectively). In addition, $14.3,9.8$, and $31.4 \%$ of the plants of the three cultivars never developed obvious symptoms of ESFY disease even if infected after long exposure to natural infections. Nevertheless, in experiment 2, Bulida was preferred to Reale d'Imola and Cafona because the last two showed adaptation difficulties in conditions differing from the native region, whereas Bulida behaved well in several European countries. On the other hand, 'Columet', 'Cremonini', and 'Sorriso' did not exhibit recovery, whereas the number of tested plants of 'Harcot' was too low to properly calculate the recovery potential.

On the basis of the PCR or RFLP analyses performed at the end of the experiment, all of the test plants had become infected by ESFY phytoplasma, independent of their symptomatic, never symptomatic, or recovered status. No reactions were given by negative controls used in DNA extraction and nested-PCR procedures. The RFLP patterns obtained from the analyzed apricot plants were the same as the reference strains LNp or LNS2 (data not shown).

Experiment 2: maintenance of the phenotypic resistance in the "progeny" of the apricot plants that stably recovered. The behavior of R1 and R2 plants as well as NR1 and NR2 individuals during the 9-year period (2003 to 2011) of natural infection-exposure is reported in Tables 2 and 3. For R1 plants, the disease prevalence was $18.8 \%$, the plant infectivity rate was $100.0 \%$, and the

Table 1. Experiment 1: behavior of 170 apricot trees of seven heirloom cultivars exposed to natural European stone fruit yellows (ESFY) inoculation at Spessa (Friuli Venezia Giulia, Italy) for 12 years (1989 to 2000)

\begin{tabular}{|c|c|c|c|c|c|}
\hline \multirow[b]{2}{*}{ Cultivar } & \multicolumn{4}{|c|}{ Number of test plants } & \multirow[b]{2}{*}{ Recovered plants } \\
\hline & Exposed & Never symptomatic ${ }^{a}$ & Dead & Symptomatic $^{b}$ & \\
\hline Bulida & 35 & 5 & 6 & $24^{d}$ & $2^{\mathrm{d}}$ \\
\hline Cafona & 61 & 6 & 7 & 48 & 4 \\
\hline Columet & 13 & 4 & 1 & 8 & 0 \\
\hline Cremonini & 12 & 0 & 4 & 8 & 0 \\
\hline Harcot & 8 & 4 & 1 & 3 & 2 \\
\hline Reale d'Imola & 35 & 11 & 2 & 22 & 2 \\
\hline Sorriso & 6 & 3 & 1 & 2 & 0 \\
\hline Total & 170 & 33 & 22 & 115 & 10 \\
\hline
\end{tabular}

\footnotetext{
a Plants that became ESFY infected but never symptomatic.

b Plants that became ESFY infected and also symptomatic (diseased).

c Plants of the 115 symptomatically infected that stably recovered.

d In experiment 2, 2 of 2 recovered and 2 of 24 symptomatic mother plants were used.
} 
plant lethality was $21.9 \%$ (Table 2 ). In the R2 plants, the disease prevalence was $2.8 \%$, the infectivity rate $95.8 \%$, and the plant lethality $5.6 \%$. Moreover, 3 of $32(9.4 \%)$ of the R1 plants and 3 of 36 $(8.3 \%)$ of the R2 plants (corresponding to an average ESFYinfectivity rate of $8.8 \%$ ) resulted in ESFY infection according to PCR or RFLP analyses in 2003 (Table 2). In the case of NR1 and $\mathrm{NR} 2$, the disease prevalence was 90.0 and $100.0 \%$ and the lethality was 24.0 and $19.0 \%$, respectively, and the infectivity rate reached $100.0 \%$ for each of the two clones (Table 3). Statistical analyses performed on the data shown in Tables 2 and 3 demonstrated that the annual disease incidence was significantly different between the $\mathrm{R}$ and NR groups of plants $(P<0.05)$, whereas the annual plant infectivity rate and the plant mortality were not significantly different.

Summarizing the results (Table 4), the mean probability of the plants becoming diseased (symptomatic) during the 9 years of exposure to natural infections was about 10 times higher (93.0 versus $10.3 \%, P<0.05)$ between the two NR clones compared with the two R clones. The mean death risk (13.2 and $22.5 \%$ for $\mathrm{R}$ and NR clones, respectively) and the mean infection risk (97.6 and $100.0 \%$ for R and NR clones, respectively) were not significantly different in the two plant populations.

None of the 66 diseased plants of the two NR clones showed recovery; in contrast, six of the seven (85.7\%) diseased plants of the two $\mathrm{R}$ clones revealed complete and stable recovery (Table 2).

The negative controls used in PCR carried out to estimate the infectivity rate did not show any reactions. RFLP analyses demonstrated that PCR-positive apricot plants were infected by ESFY phytoplasma.

The commercial fruit production of symptomatic apricot plants, grafted on Rubira peach, was nil, whereas the production of infected but nonsymptomatic plants was not distinguishable from the phytoplasma-free plants (data not shown). The mean circumference of the plants obtained from recovered mothers measured during 2011 was $41.0 \mathrm{~cm}$, whereas the mean value obtained from nonrecovered ones was $32.0 \mathrm{~cm}$. Statistical analyses demonstrated that the mean circumference between the two groups of plants was highly significant $(P<0.001)$.

\section{Discussion}

As shown in Table 1 (experiment 1), none of the varieties of apricot tested under the conditions of natural infection pressure behaved as resistant to ESFY. In fact, based on PCR or RFLP analyses, all of the exposed plants were ESFY infected. A high proportion $(115$ of $170,67.6 \%)$ of the plants developed typical symptoms of the disease. These cultivars consequently were neither resistant nor tolerant to ESFY.

In all, 10 of $115(8.7 \%)$ of the symptomatic plants recovered completely and stably from the disease. A status of acquired tolerance of an epigenetic nature was hypothesized to have occurred in stably recovered plants.

As described before, to experimentally verify this intriguing hypothesis, we exposed two "recovered clones" (R1 and R2) and two

Table 4. Experiment 2: infection, disease and death risk of 139 apricot plants either cloned from recovered (R) or nonrecovered (NR) mothers when exposed for 9 years to natural infections

\begin{tabular}{lccc}
\hline & \multicolumn{3}{c}{ Risk $(\%)$} \\
\cline { 2 - 4 } Plant groups & Infection $^{\mathbf{a}}$ & Disease $^{\mathbf{b}}$ & Death $^{\mathbf{c}}$ \\
\hline R1 + R2 & 97.6 & 10.3 & 13.2 \\
NR1 + NR2 & 100 & 93.0 & 22.5 \\
\hline
\end{tabular}

a Probability of the recovered (R) and nonrecovered (NR) clones becoming infected during the infection exposure (based on polymerase chain reaction tests).

${ }^{\mathrm{b}}$ Probability of the plants becoming symptomatic (= diseased).

c Probability of the test plant dying.

Table 2. Experiment 2: behavior of cloned plantlets (R1 and R2) derived from recovered mother plants after 9 years of exposure in an European stone fruit yellows (ESFY)-infected area (Friuli Venezia Giulia, Italy)

\begin{tabular}{|c|c|c|c|c|c|c|c|c|c|c|}
\hline \multirow[b]{2}{*}{ Plants } & \multicolumn{9}{|c|}{ Years $^{a}$} & \multirow[b]{2}{*}{ Cumulative data } \\
\hline & 2003 & 2004 & 2005 & 2006 & 2007 & 2008 & 2009 & 2010 & 2011 & \\
\hline \multicolumn{11}{|l|}{$\mathrm{R} 1$} \\
\hline Annual DI ${ }^{\mathrm{b}}$ & $0 / 32$ & $0 / 32$ & $0 / 32$ & $0 / 32$ & $4 / 32$ & $0 / 32$ & $1 / 32$ & $0 / 25$ & $1 / 25$ & Disease: $6 / 32(18.8 \%)^{c}$ \\
\hline Annual PI rate ${ }^{d}$ & $3 / 32$ & nt & $7 / 17$ & nt & $15 / 17$ & $31 / 31$ & $31 / 31$ & $24 / 24$ & $17 / 17$ & Total PI rate $(100.0 \%)$ \\
\hline Plant mortality $\mathrm{e}$ & 0 & 0 & 0 & 0 & 0 & 0 & 0 & 7 & 0 & Lethality: $7 / 32(21.9 \%)$ \\
\hline \multicolumn{11}{|l|}{$\mathrm{R} 2$} \\
\hline Annual DI & $0 / 36$ & $0 / 36$ & $0 / 36$ & $0 / 34$ & $0 / 34$ & $0 / 34$ & $1 / 34$ & $0 / 34$ & $0 / 34$ & Disease: $1 / 36(2.8 \%)$ \\
\hline Annual PI rate & $3 / 36$ & $0 / 17$ & $9 / 13$ & $14 / 25$ & $20 / 25$ & $20 / 24$ & $22 / 24$ & $21 / 24$ & $23 / 24$ & Total PI rate (95.8\%) \\
\hline Plant mortality & 0 & 0 & 0 & 2 & 0 & 0 & 0 & 0 & 0 & Lethality: $2 / 36(5.6 \%)$ \\
\hline
\end{tabular}

a Abbreviation: $\mathrm{nt}=$ not tested.

${ }^{\mathrm{b}}$ Annual disease incidence $(\mathrm{DI})=$ proportion of newly diseased plants per year $(=$ symptomatic) versus exposed plants.

${ }^{c}$ Disease prevalence (Disease) $=$ cumulative proportion of plants that became ESFY diseased versus exposed plants.

$\mathrm{d}$ Annual plant infectivity $(\mathrm{PI})$ rate = proportion of plants that were positive to the polymerase chain reaction-tests versus exposed plants.

${ }^{\mathrm{e}}$ Mortality $=$ number of the ESFY-infected plants that died per year and lethality $=$ the proportion of the total number of dead plants versus exposed plants.

Table 3. Experiment 2: behavior of cloned plantlets (NR1 and NR2) derived from nonrecovered mother plants after 9 years of exposure in an European stone fruit yellows ESFY-infected area (Friuli Venezia Giulia)

\begin{tabular}{|c|c|c|c|c|c|c|c|c|c|c|}
\hline \multirow[b]{2}{*}{ Plants } & \multicolumn{9}{|c|}{ Years $^{\mathrm{a}}$} & \multirow[b]{2}{*}{ Cumulative data } \\
\hline & 2003 & 2004 & 2005 & 2006 & 2007 & 2008 & 2009 & 2010 & 2011 & \\
\hline \multicolumn{11}{|l|}{ NR1 } \\
\hline Annual DI ${ }^{\mathrm{b}}$ & $42 / 50$ & $1 / 46$ & $2 / 44$ & $0 / 40$ & $0 / 39$ & $0 / 39$ & $0 / 39$ & $0 / 38$ & $0 / 38$ & Disease: $45 / 50(90.0 \%)^{c}$ \\
\hline Annual PI rate ${ }^{d}$ & $5 / 11$ & nt & $4 / 4$ & $4 / 8$ & $29 / 36$ & $22 / 22$ & $22 / 22$ & $38 / 38$ & $38 / 38$ & Total PI rate $(100.0 \%)$ \\
\hline Plant mortality ${ }^{\mathrm{e}}$ & 0 & 4 & 2 & 4 & 1 & 1 & 0 & 1 & 0 & Lethality: $12 / 50(24.0 \%)$ \\
\hline \multicolumn{11}{|l|}{ NR2 } \\
\hline Annual DI & $1 / 21$ & $3 / 21$ & $9 / 21$ & $8 / 21$ & $0 / 20$ & $0 / 19$ & 0/19 & $0 / 17$ & $0 / 17$ & Disease: $21 / 21(100.0 \%)$ \\
\hline Annual PI rate & nt & nt & $7 / 11$ & nt & $17 / 20$ & $19 / 19$ & $19 / 19$ & $17 / 17$ & $17 / 17$ & Total PI rate $(100.0 \%)$ \\
\hline Plant mortality & 0 & 0 & 0 & 0 & 1 & 1 & 0 & 2 & 0 & Lethality: $4 / 21(19.0 \%)$ \\
\hline
\end{tabular}


"nonrecovered symptomatic clones" (NR1 and NR2) of Bulida apricot to natural phytoplasma infections (experiment 2). The main aim of this second experiment was to verify whether the progeny of a mother plant that become tolerant to ESFY do continue to behave as tolerant. From experiment 1, both never-symptomatic and stably recovered mother plants developed the status of acquired tolerance. However, dealing with the biological system apricot-ESFY, we learned that recovery is a clear and prompt signal of acquired tolerance. There is a precise line between the status of disease and the beginning of the acquired tolerance that we can easily identify in the field without using PCR analyses. Therefore, plants cloned from recovered mother plants were used in experiment 2; studies on the behavior of cloned plants from never-symptomatic mothers are in progress. The most critical and severe experimental conditions were planned for the second experiment, such as a place with a known high natural pressure of ESFY-infection (Friuli Venezia Giulia region), a rootstock that infers sensitivity to the plant (Rubira peach), and a susceptible apricot cultivar (Bulida). The expected mean risk for the $\mathrm{R}$ clones to become diseased in the experimental conditions was $10.3 \%$ (Table 4). Nevertheless, six of the seven diseased plants $(85.7 \%)$ recovered stably from the disease (Table 2). As a consequence, the real probability of the R-clone plants becoming and remaining diseased decreased from 10.3 to only $1.5 \%$. In contrast, the plants of the two NR clones showed a mean disease risk of $93.0 \%$ (Table 4). None of the plants cloned from nonrecovered mother plants showed signs of recovery (Table 3).

It is interesting to note that all clones, derived from recovered and nonrecovered mother plants, were positive using PCR assays. Based on the results from the two experiments we described, we propose that acquired tolerance occurred in stably recovered mother plants and continued in the propagated clones. In practice, our results show that it is possible to obtain plants completely tolerant to the disease from stably recovered mother plants of apricot. Comparable results have been described by Morvan et al. (33) and Castelain et al. (8) in France. However, by adopting PCR techniques available, especially after 1995, in our work, we could definitely demonstrate that recovery in apricot consisted of the disappearance of the symptoms but not of the agent. We also demonstrated that the never-symptomatic apricot plants were in fact all infected and, therefore, tolerant but not resistant to ESFY. Moreover, the natural vector of ESFY was discovered by us (9), after the French studies $(8,12,32,34)$. Consequently, it was possible to prove that the real natural infection pressure in the selected area was high (15).

In the experiences performed in France $(8,34)$, the recovery in apricot was ascribed to a cross-protection process. A "graft-transmissible protective factor" (i.e., avirulent or low-virulent strains of the phytoplasma) was proposed as the cause of recovery (34). In Germany, a work by Kison and Seemueller (19) has shown the presence in nature of 20 strains of ESFY with different grades of virulence, from nearly avirulent to aggressive. In a recent overview of ESFY (27), the authors agreed that "it is conceivable that strains interference (cross protection) play a key role in the recovery phenomenon in which protectant strains may suppress severe strains". Our recent results achieved in Friuli on ESFY do not confirm the interference based on cross protection in recovered-tolerant apricot, mainly for two reasons. (i) In 2003, the mean percentage of plants of the two R groups that were ESFY infected was only $8.8 \%$ (Table 2), meaning that $91.2 \%$ of the plants derived from recovered mothers were not hosting any kind of ESFY strain, including the protectant or avirulent ones, before being exposed to natural infections. Moreover, after 9 years of exposure, the mean percentage of diseased plants was only $10.3 \%(1.5 \%$, considering the stably diseased plants) of the exposed ones. (ii) It was not possible to establish a correlation between symptom severity and ESFY phytoplasma strains characterized on the basis of aceF gene (29). In particular, we found the same ESFY phytoplasma strains in single or in mixed infections in either symptomatic or nonsymptomatic apricot plants.
As a consequence, in our case, we are in favor of a plant-mediated tolerance that is transmissible from plant to plant by grafting instead of a cross-protection process based on protectant avirulent strains of the pathogen. As already stated, this type of tolerance is not a genetic character of the plants. In fact, not all of the phytoplasma-diseased plants belonging to a genetically uniform clone recover and become tolerant. The cited "tolerance" corresponds to "phenotypic resistance" (3) or "disease resistance" (4).

We found that spontaneous and stable recovery can occur in small numbers of ESFY-diseased apricot plants. In plants cloned from recovered mother trees, the tendency toward recovery is greatly increased. Even if recovery is rather rare in commercial varieties of apricot, stably recovered plants are precious because they act as a visual signal of possible acquired tolerance against ESFY. Indeed, tolerance against ESFY has been demonstrated here as transmissible by grafting, with a very high efficiency, to clonally propagated plants.

Other studies across diverse plant families support the transmission of induced resistances (48). According to several authors $(13,48)$, acquired resistance is associated with numerous pathogenesis-related proteins and these are generally thought to be effective against a large spectrum of different pathogens and related strains and to be long lasting.

Acquired tolerances could enable profitable apricot cultivation in ESFY-infected areas. Because the graft transmission rate of ESFY phytoplasma from recovered infected plants is low (8.8\%), it is possible to obtain apricot plants that are both tolerant and ESFY phytoplasma free. The availability of plants with epigenetic tolerance or resistance against infective agents of epidemic diseases could represent a revolutionary means of practical disease-control. Certainly, it would allow innovative strategies not only to cultivate plants in infected areas but also to attempt disease eradications. Using plants with acquired resistance or tolerance, the level of the resilience of the cultivated system will be enhanced. This will contribute to decreased use of chemicals and pesticides. Compared with the classic cross-protection, the utilization of epigenetically improved pathogen-free plants is certainly less controversial.

The research has to be continued to verify at least how long (for how-many successive generations) the status of acquired tolerance is maintained in plants subcloned by grafting.

Based on our results with apricot, we propose that acquired tolerance should be investigated further, not only in the apricot/ ESFY system. In this context, we suggest looking preferentially for acquired resistance or tolerance that occurs naturally in plants. In fact, we strongly believe that tolerant plants obtained in the field have high probabilities to maintain the same tolerant status once reintroduced in natural conditions. There is a rich literature concerning attempts to artificially induce plant resistance mechanisms against various pathogens by using chemical or biological elicitors $(5,14,18,24,44,49)$. However, it is rare that results achieved in experimental conditions have been successfully repeated in the field (6).

\section{Acknowledgments}

This research was supported by MIUR (Italy), PRIN project: 2005074429_001 'Studio della S.A.R. (Systemic Acquired Resistance) in connessione con il recovery in piante affette da fitoplasmi'. We thank A. Purcell, University of California, Berkeley, who made helpful suggestions; E. Refatti, Emeritus Professor of the University of Udine, who began this long experience with us; L. Cantrill (Out of site English, Sydney, Australia) for revision of the English text; and S. Grisan, University of Udine, for statistical analyses.

\section{Literature Cited}

1. Ahmad, J. N., and Eveillard, S. 2011. Study of the expression of defense related protein genes in stolbur $\mathrm{C}$ and stolbur PO phytoplasma-infected tomato. Bull. Insectol. 64 (Suppl.):159-160.

2. Ahrens, U., and Seemüller, E. 1992. Detection of DNA of plant pathogenic mycoplasmalike organisms by a polymerase chain reaction that amplifies a sequence of the 16S rRNA gene. Phytopathology 82:828-832.

3. Bonasera, J. M., Jihyun, F. K., and Beer, S. V. 2006. PR genes of apple: identification and expression in response to elicitors and inoculation with Erwinia amylovora. BMC Plant Biol. 6:23.

4. Bos, L., and Parlevliet, J. E. 1995. Concepts and terminology on plant/pest 
relationships: toward consensus in plant pathology and crop protection. Annu. Rev. Phytopathol. 33:69-102.

5. Bressan, A., and Purcell, A. H. 2005. Effect of benzothiadiazole on transmission of X-Disease phytoplasma by the vector Colladonus montanus to Arabidopsis thaliana, a new experimental host plant. Plant Dis. 89:11211124.

6. Brisset, M. N., Cesbron, S., Thomson, S. V., and Paulin, J. P. 2000. Acibenzolar-S-methyl induces the accumulation of defense-related enzymes in apple and protects from fire blight. Eur. J. Plant Pathol. 106:529-536.

7. Bulgari, D., Casati, P., Crepaldi, P., Daffonchio, D., Quaglino, F., Brusetti, L., and Bianco, P. A. 2011. Restructuring of endophytic bacterial communities in grapevine yellows-diseased and recovered Vitis vinifera L. plants. Appl. Environ. Microbiol. 77:5018-5022.

8. Carraro, L., Osler, R., Loi, N., Ermacora, P., and Refatti, E. 1998. Transmission of the European stone fruit yellows phytoplasma by Cacopsylla pruni. J. Plant Pathol. 80:233-239.

9. Castelain, C., Chastellière, M. G., Jullian, J. P., Morvan, G., and Lemaire, J. M., 1997. La premonition contre l'enroulement chlorotique de l'abricotier. Phytoma 493:39-44.

10. Caudwell, A. 1961. Les phénomènes de rétablissement chez la flavescence dorée de la vigne. Ann. Epiphyt. 12:347-354.

11. Deng, S., and Hiruki, D. 1991. Amplification of 16 S rRNA genes of culturable and not culturable mollicutes. J. Microbiol. Methods 14:53-61.

12. Dosba, F., Lansac, M., Mazi, K., Garnier, M., and Eyquard, J. P. 1991. Incidence of different diseases associated with mycoplasma-like organisms in different species of Prunus. Acta Hortic. 283:311-320.

13. Durrant, W. E., and Dong, X. 2004. Systemic acquired resistance. Annu. Rev. Phytopathol. 42:185-209.

14. Gamalero, E., D’Amelio, R., Musso, C., Cantamessa, S., Pivato, B., D'Agostino, G., Duan J., Bosco, D., Marzachi, G., and Berta, G. 2010. Effects of Pseudomonas putida S1Pf1Rif against Chrysanthemum yellows phytoplasma infection. Phytopathology 100:805-813.

15. Ermacora, P., Ferrini, F., Loi, N., Martini, M., and Osler, R. 2011. Population dynamics of Cacopsylla pruni and 'Candidatus Phytoplasma prunorum' infection in North-Eastern Italy. Bull. Insectol. 64:S143-S144.

16. Feil, H., Feil, W. S., and Purcell, A. H. 2003. Effects of date of inoculation on the within-plant movement of Xylella fastidiosa and persistence of Pierce's disease within field grapevines. Phytopathology 93:244-251.

17. Jarausch, W., Saillard, C., Helliot, B., Garnier, M., and Dosba, F. 2000. Genetic variability of apple proliferation phytoplasmas as determined by PCR-RFLP and sequencing a non-ribosomal fragment. Mol. Cell Probes 14:17-24.

18. Kessmann, H., Staub, T., Hoffmann, C., Maetzhe, T., Herzog, J., Ward, E., Uknes, S., and Ryals, J. 1994. Induction of systemic acquired disease resistance in plants by chemicals. Annu. Rev. Phytopathol. 32:439-459.

19. Kison, H., and Seemüller, E. 2001. Differences in strain virulence of the European stone fruit yellows phytoplasma and susceptibility of stone fruit trees on various rootstocks to this pathogen. J. Phytopathol. 149:533-541.

20. Kunze, L. 1976. The effect of different strains of apple proliferation on the growth and crop of infected trees. Mitt. Biol. Bundesanst. Land Fortwirtsch. Berlin-Dahlem. 170:107-115.

21. Langer M., and Maixner, M. 2004. Molecular characterisation of grapevine yellows associated phytoplasmas of the stolbur-group based on RFLPanalysis of non-ribosomal DNA. Vitis 43:191-200.

22. Lee, I.-M., Davis, R., and Gundersen-Rindal, D. E., 2000. Phytoplasma: phytopathogenic mollicutes. Annu. Rev. Microbiol. 54:221-255.

23. Lee, I.-M., Martini, M., Marcone, C., and Zhu, S. 2004. Classification of phytoplasma strains in the Elm yellows group $(16 \mathrm{SrV})$ and proposal of 'Candidatus Phytoplasma ulmi' for the phytoplasma associated with Elm yellows. Int. J. Syst. Evol. Microbiol. 64:337-347.

24. Leljak-Levanic, D., Jezic, M., Cesar, V., Ludwig-Muller, J., Lepedus, H., Mladinic, M., Katic, M., and Curkovic-Perica, M. 2010. Biochemical and epigenetic changes in phytoplasma-recovered periwinkle after indole-3-butyric acid treatment. J. Appl. Microbiol. 109:2069-2078.

25. Lorenz, K. H., Schneider, B., Ahrens, U., and Seemüller, E. 1995. Detection of the apple proliferation and pear decline phytoplasmas by PCR amplification of ribosomal and nonribosomal DNA. Phytopathology 85:771-776.

26. Maixner, M., Kröhner, D., and Kappel, Y. 2011. Symptom remission and recovery in 'bois noir' infected grapevines. Bull. Insectol. 64 (Suppl.):S175S176.

27. Marcone, C., Jarausch, B., and Jarausch, W. 2010. 'Candidatus Phytoplasma prunorum', the causal agent of European stone fruit yellows: an overview. J. Plant Pathol. 92:19-34.

28. Martini, M., Botti, S., Marcone C., Marzachì C., Casati, P., Bianco, P. A.,
Benedetti, R., and Bertaccini, A. 2002. Genetic variability among Flavescence dorée phytoplasmas from different origin in Italy and France. Mol. Cell. Probes.16:197-208.

29. Martini, M., Ferrini, F., Danet, J. L., Ermacora, P., Sertkaya, G., Delić, D., Loi, N., Foissac, X., and Carraro, L. 2010. PCR/RFLP based method for molecular characterization of 'Candidatus Phytoplasma prunorum' strains using acef gene. Julius Kühn Archiv. 427:386-391.

30. Martini, M. Musetti, R., Grisan, S., Polizzotto, R., Borselli, S., Pavan, F., and Osler, R. 2009. DNA-dependent detection of the grapevine fungal endophytes Aureobasidium pullulans and Epicoccum nigrum. Plant Dis. 93:993-998.

31. Morone, C., Boveri, M., Giosuè, S., Gotta P., Rossi, V., Scapin I., and Marzachì, C. 2007. Epidemiology of flavescence dorèe in vineyards in northwestern Italy. Phytopathology 97:1422-1427.

32. Morvan, G. 1977. Apricot chlorotic leaf roll. EPPO Bull. 7:37-55.

33. Morvan, G., Castelain, C., and Arnoux, M., 1986. Prospective for the control of apricot chlorotic leaf roll a micoplasma disease, by cross protection. Acta Hortic. 192:167-174.

34. Morvan, G., Castelain, C., Chastellière, M.-G., and Audergon, J. M. 1991. An account of the attempts at controlling apricot chlorotic leaf roll with cross protection. Acta Hortic. 293:555-561.

35. Musetti, R., Farhan, K., De Marco, F., Polizzotto, R., Paolacci, A. R., Ciaffi, M., Ermacora, P., Grisan, S., Santi, S., and Osler, R. 2013. Differentiallyregulated defence genes in Malus domestica during phytoplasma infection and recovery. Eur. J. Plant Pathol. 136:13-19.

36. Musetti, R., Grisan, S., Polizzotto, R., Martini, M., Paduano, C., and Osler, R. 2011. Interactions between 'Candidatus phytoplasma mali' and the apple endophyte Epicoccum nigrum in Catharanthus roseum plants. J. Appl. Microbiol. 110:746-756.

37. Musetti, R., Marabottini, R., Badiani, M., Martini, M., Sanità di Toppi, L., Borselli, S., Borgo, M., and Osler, R. 2007. On the role of $\mathrm{H}_{2} \mathrm{O}_{2}$ in the recovery of grapevine (Vitis vinifera cv. Prosecco) from Flavescence dorée disease. Funct. Plant Biol. 34:750-754

38. Musetti, R., Paolacci, A., Ciaffi, M., Tanzarella, O. A., Polizzotto, R., Tubaro, F., Mizzau, M., Ermacora, P., Badiani, M., and Osler, R. 2010. Phloem cytochemical modification and gene expression following the recovery of apple plants from apple proliferation disease. Phytopathology 100:390-399.

39. Musetti, R., Sanità di Toppi, L., Ermacora, P., and Favali, M. A. 2004. Recovery in apple trees with the apple proliferation phytoplasma: an ultrastructural and biochemical study. Phytopathology 94:203-208.

40. Musetti, R., Sanità di Toppi, L., Martini, M., Ferrini, F., Loschi, A., Favali, M. A., and Osler, R. 2005. Hydrogen peroxide localisation and antioxidan status in the recovery of apricot plants from European stone fruit yellows. Eur. J. Plant Pathol. 112:53-61.

41. Osler, R., Carraro, L., Loi, N., and Refatti, E. 1993. Symptom expression and disease occurrence of a yellows disease of grapevine in Northern Italy. Plant Dis. 77:496-498.

42. Patui, S., Bertolini, A., Clincon, L., Ermacora, P., Braidot, E., Vianello, A., and Zancani, M. 2012. Involvement of plasma membrane peroxidases and oxylipin pathway in the recovery from phytoplasma disease in apple (Malus domestica). Physiol. Plant. 148:200-213.

43. Purcell, A. H. 1977. Cold therapy for Pierce's disease of grapevines. Plant Dis. 64:388-390.

44. Romanazzi, G., D’Ascenzo, D., and Murolo, S. 2009. Field treatment with resistance inducers for the control of grapevine bois noir. J. Plant Pathol. 91:677-682.

45. Schneider, B., Seemüller, E., Smart, D., and Kirkpatrick, B. C. 1995. Phylogenetic classification of plant pathogenic mycoplasma-like organism or phytoplasmas. Pages 369-380 in: Molecular and Diagnostic Procedures in Mycoplasmology, Vol. I. S. Razin and J. G., Tully, eds. Academic Press, San Diego, CA.

46. Seemüller, E., Garnier, M., and Schneider, B. 2002. Mycoplasmas of plants and insects. Pages 91-115 in: Molecular Biology and Pathogenicity of Mycoplasmas. S. Razin and R. Herrmann, eds. Kluwer Academic/Plenum, Publishers, New York.

47. Seemüller, E., Kiss E., Sule, S., and Schneider, B., 2010. Multiple infection of apple trees by distinct strains of 'Candidatus Phytoplasma mali' and its pathological relevance. Phytopathology 100:863-870.

48. Sticher, L., Mauch-Mani, B., and Metraux, J. P. 1997. Systemic acquired resistance. Annu. Rev. Phytopathol. 35:235-270.

49. Van Loon, L. C., Rep, M., and Pieterse, C. M. J. 2006. Significance of inducible defence-related proteins in infected plants. Annu. Rev. Phytopathol. 44:135-162.

50. Weintraub, P. G., and Beanland, L. 2006. Insect vectors of phytoplasmas. Annu. Rev. Entomol. 51:91-111. 